\title{
Spent Coffee Grounds Do Not Control Cycad Aulacaspis Scale
}

\author{
Tracy Monique Magellan ${ }^{1}$, Chad Husby, Stella Cuestas, \\ and M. Patrick Griffith
}

AdDITIONAL INDEX WORDs. asian cycad scale, Aulacaspis yasumatsui, coffee beans, mulch, neem oil, orange oil, Coffea arabica, Cycas debaoensis, Cycas micronesica

\begin{abstract}
Summary. Cycad aulacaspis scale [CAS (Aulacaspis yasumatsui)] is a highly destructive pest insect worldwide. CAS feeds on cycad (Cycas sp.) plantings and is also posing a problem for the foliage industry. The use of spent coffee grounds to prevent or control CAS has received increased popularity in the last few years. This study assesses whether the application of spent coffee grounds is a realistic control method against CAS, and whether spent coffee grounds can be successfully used as a natural alternative to chemical pesticides. Two tests were performed during Summer 2010 and 2011 . The first experiment assessed seven treatments: five coffee treatments, neem oil, and orange oil to control CAS on the debao cycad (Cycas debaoensis). In the second experiment, only coffee mulch was tested against the control on the debao cycad and fadang (Cycas micronesica). There was no statistical evidence of a difference between the control and the coffee mulch treatment with regard to infestation (insects per square centimeter). Soil $\mathrm{pH}$ differences were confirmed between control and coffee treatments, with the application of coffee mulch lowering $\mathrm{pH}$ by an average of 0.48 . Spent coffee grounds did not have an effect on cycad mortality, but neem oil and orange oil increased cycad mortality.
\end{abstract}

$\mathrm{C}$ AS is a highly destructive pest in southern Florida and worldwide. In 1996, CAS was introduced to Miami, FL, from southern China or Thailand (Germain and Hodges, 2007; Howard and Weissling, 1999; Howard et al., 1999; Weissling et al., 1999). CAS is highly detrimental to cycads. Since its introduction, thousands of cycads have been killed in the Miami area (Mannion, 2003; Whitelock, 2002). CAS is also the greatest threat to the native population of fadang in Guam (Marler and Muniappan, 2006). Its abundance is taking a toll on cycad plantings and is posing a problem for the foliage industry (Emshousen et al., 2004; Wiese et al., 2005; Woods, 2007). The ornamental horticulture industry has suffered millions of dollars in losses because of CAS (Mannion, 2003; Woods, 2007).

\footnotetext{
Montgomery Botanical Center, 11901 Old Cutler Road, Coral Gables, FL 33156

We thank John DeMott from Redland Nursery in Homestead, FL, for his generous donation of the Cycas debaoensis used in the two experiments. We also thank Michael Calonje, cycad curator of MBC, for allocating the Cycas micronesica for the second round of testing; Starbucks Coffee Company for their donation of pounds and pounds of grounds for the study; Vickie Murphy for her horticultural expertise; and Jack Bauer, Ansel Thomas, and Hostilio Torres for constructing the shadehouse.

${ }^{1}$ Corresponding author. E-mail: tracym@montgomery botanical.org.
}

The debao cycad is critically endangered, and the population trend is decreasing (International Union for Conservation of Nature, 2010). Artificial propagation in the commercial nursery industry will be highly beneficial to the species, by minimizing collecting pressure on the wild populations. Its bipinnate leaf structure makes it an attractive foliage plant, though its susceptibility to CAS may deter nurseries from propagating this species.

Since 2006, there has been discussion in the cycad enthusiast community regarding the benefits of coffee grounds (Broome, 2007; Kelly, 2008); yet, no scientific studies support these claims (Popenoe, 2010). Two methods of application have been discussed: 1) a foliar application of coffee grounds mixed with water and 2) coffee mulch at the base of the plants. In prior research, foliar contact pesticide applications have not worked well to control CAS because of the heavy-scale concentrations on the

\begin{tabular}{llll}
\hline $\begin{array}{l}\text { Units } \\
\begin{array}{l}\text { To convert U.S. to SI, } \\
\text { multiply by }\end{array}\end{array}$ & U.S. unit & SI unit & $\begin{array}{l}\text { To convert SI to U.S., } \\
\text { multiply by }\end{array}$ \\
\hline 29.5735 & $\mathrm{fl} \mathrm{oz}$ & $\mathrm{mL}$ & 0.0338 \\
3.7854 & $\mathrm{gal}$ & $\mathrm{L}$ & 0.2642 \\
2.54 & inch $(\mathrm{es})$ & $\mathrm{cm}$ & 0.3937 \\
$\mathrm{l}$ & $\mathrm{mmho} \cdot \mathrm{cm}^{-1}$ & $\mathrm{mS} \cdot \mathrm{cm}^{-1}$ & 1
\end{tabular}

undersides of leaves (Howard and Weissling, 1999; Smith and Cave, 2006; Wiese et al., 2005) and roots (Howard et al., 1999; Weissling et al., 1999), which are difficult to cover with foliar sprays (Hodges et al., 2003; Smith and Cave, 2006).

At Montgomery Botanical Center (MBC, Coral Gables, FL), research on the control and integrated pest management of CAS has been performed (Wiese and Mannion, 2007). Mannion (2003) performed a study examining possible chemical deterrents, many of which were not viable because of phytotoxicity. Experiments on biological control of CAS were also conducted at MBC (Cave, 2006; Wiese and Mannion, 2007; Wiese et al., 2005).

Potential insecticidal activity of coffee was tested on leaf-cutting ant (Atta sexdens rubropilosa) with negative results (Miyashira et al., 2011) and on mosquito (Aedes aegypti) with positive results (Guirado and Bicudo, 2007; Laranja et al., 2003).

Prior studies indicated neem oil (Fiaz et al., 2012; Mamoon-urRashid et al., 2012; Tang et al., 2002) and orange oil (Ashok et al., 2007; Hollingsworth, 2005; Zunino et al., 2012 ) have insecticidal properties.

In 2009 , a preliminary study was conducted at MBC involving a variety of cycads that were mulched with spent coffee grounds. The goal of the study was to observe whether there would be a benefit with regard to CAS control. The results appeared to be positive, but lacked quantitative rigor and sufficient control. This study was conducted to more rigorously determine whether spent coffee grounds are an effective control method for CAS.

\section{Materials and methods}

Three types of coffee application were used: spent coffee mulch, spent coffee tea, and a combination of spent coffee mulch and spent coffee tea. Half doses were included among the treatments to assess whether treatment thresholds may exist. Leaflet area, soil $\mathrm{pH}$, and total number of 
CAS present were measured. After initial infestation counts were made, treatments began. Neem and orange oil treatments were also applied. Treatments were reapplied weekly.

ExPT. 1. In the first experiment, 40 debao cycads of similar size were selected at a nursery and potted in 3-gal pots. We used cycad potting mix, which is composed of Fafard organic soil conditioner (Conrad Fafard, Agawam, MA); sand, coarse silica sand (Florida Silica Sand Co., Fort Lauderdale, FL); and expanded clay (Hydroton; Florida Garden Supplies, Miami, FL) in a 1:1:1 ratio by volume. The plants were grown in full sun from 13 May to 9 Nov. 2010 (Fig. 1). Spent coffee grounds were collected from local coffeehouses weekly. Five replicates of six coffee treatments were applied: 1) no treatment (control), 2) spent coffee mulch, 3) coffee tea, 4) halfstrength coffee tea, 5 ) half-strength coffee mulch, and 6) mulch and coffee tea. Treatments 7 and 8 were orange oil and neem oil, respectively.

Baseline $\mathrm{pH}$ and electrical conductivity (EC) pour-through measurements were taken before beginning treatments using a $\mathrm{pH} / \mathrm{EC}$ meter (AGRI-METER model AG6/pH; Myron L Co., Carlsbad, CA). An irrigation water leachate pour-through procedure was used (Bilderback, 2001).
Soil was saturated and after $30 \mathrm{~min}$, $12 \mathrm{fl} \mathrm{oz}$ of irrigation water (well water) was poured on each pot. The leachate was collected in a plastic saucer. EC and pH were measured [following methodology from Cavins et al. (2000), Bilderback (2001), and Whipker et al. (2001)]. At the start of the experiment, the $\mathrm{pH}$ of the well water was 7.2 and $\mathrm{EC}$ was $1 \mathrm{mmho} / \mathrm{cm}$.

Photos and initial insect counts were taken showing baseline level of scale infestation for 40 individuals. In all cases, no live insects were found on the experimental plants at the start of the experiment, but CAS is prevalent on the property's large cycad collection located near the experimental area. Plants were watered on the same schedule, two to three times a week.

Coffee mulch treatment consisted of $500 \mathrm{~mL}$ compressed spent espresso grounds. Half mulch treatment was $250 \mathrm{~mL}$ compressed spent espresso grounds. Compressed espresso grounds were used to standardize the quantity of coffee and water in all treatments. Drip coffee grounds were not used because they are more variable in initial water content.

The coffee tea was made by mixing $500 \mathrm{~mL}$ spent coffee grounds in 1 gal of water to steep overnight. The following day the coffee tea was filtered using a stainless steel coffee

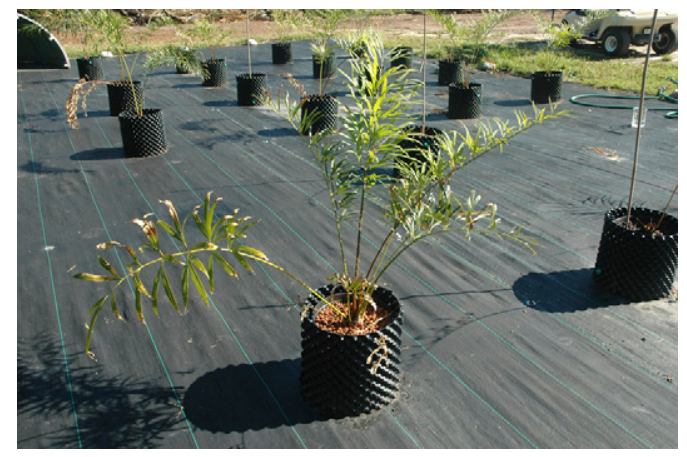

Fig. 1. Full sun experiment testing coffee treatments based on natural products (coffee mulch, coffee tea, half-strength coffee tea, half-strength coffee mulch, and mulch + coffee tea, neem oil, and orange oil) for control of cycad aulacaspis scale on debao cycads at Montgomery Botanical Center, Coral Gables, FL, in 2010. Coffee mulch treatment consisted of $500 \mathrm{~mL}$ spent coffee per week. Coffee tea treatment consisted of $500 \mathrm{~mL} / \mathrm{gal}$ spent coffee applied in one 0.5 -gal treatment per week. The half-strength coffee tea treatment consisted of the coffee tea treatment above diluted in a 1:1 ratio with water applied in one 0.5-gal treatment per week. Halfstrength coffee mulch treatment consisted of $250 \mathrm{~mL}$ spent coffee per week. Mulch + tea consisted of applications of the coffee mulch and the coffee tea treatments. Neem oil treatment consisted of $60 \mathrm{~mL} / \mathrm{gal}$ neem oil applied in one 0.5 -gal treatment per week. Orange oil treatment consisted of $60 \mathrm{~mL} / \mathrm{gal}$ orange oil applied in one 0.5 -gal treatment per week; $1 \mathrm{~mL} / \mathrm{gal}=0.0338 \mathrm{fl} \mathrm{oz} / \mathrm{gal}=0.2642 \mathrm{~mL} \cdot \mathrm{L}^{-1}$, $1 \mathrm{gal}=3.7854 \mathrm{~L}$.

filter (\#4 Cone Permanent Golden \#GF2 14; Medelco, Bridgeport, CT) and the solution was sprayed on the adaxial and abaxial leaflet surfaces of each plant in that treatment. The remaining coffee tea was used as a drench to saturate the root area. For the $1 / 2$ tea solution, the same coffee tea recipe was used and diluted in a $1: 1$ ratio with water. Total dosage per plant (spray + drench) was 0.5 gal.

Orange oil (product 9492; GardenVille, Austin, TX) and neem oil leaf polish (model SP-NO8; Dyna-Gro Nutrition Solutions, Richmond, CA) were applied at a concentration of $60 \mathrm{~mL}$ per gallon. In these treatments, the adaxial and abaxial surfaces of the leaflets were fully sprayed and the remainder of the solution was applied as a soil drench. The oil treatments were also applied at a total dose per plant (spray + drench) of $0.5 \mathrm{gal}$.

Five leaflets were collected from each plant and CAS insects were counted on 23 Sept. and 8 Nov. 2010. Leaf areas and insect counts were measured using ImageJ64 (Rasband, 2012), and insects per square centimeter were calculated.

Infestation densities were compared via one-way analysis of variance (ANOVA) using JMP (version 9.0; SAS Institute, Cary, NC). Binomial confidence intervals for plant mortality were calculated using Excel 2002 (Microsoft Corp., Redmond, WA).

Expt. 2. We conducted a followup experiment from 15 July to 3 Nov. 2011 . We tested 40 plants (20 debao cycads and 20 fadang) comparing coffee mulch (500-mL treatments) vs. control under a shadehouse constructed with $63 \%$ woven shadecloth (Fig. 2). The soil mixture used was the same formula as in Expt. 1. We inoculated each of the 40 plants with a fully infested leaflet measuring $10 \times 2 \mathrm{~cm}$. Five leaflets were collected from each plant and CAS insects were counted on 1 Sept. and 3 Nov. 2011. Leaf areas and insect counts were measured using ImageJ64. Plant mortality data were also recorded (Table 1 ). Infestation densities were compared via one-way ANOVA using JMP (version 9.0).

\section{Results}

The spent coffee mulch treatment did not affect the number of insects per square centimeter present when compared with the control (Figs. 3 and 4), nor did it have an 
effect on cycad mortality (Table 1). No plants treated with coffee mulch in Expt. 2 died.

The boxplots in Fig. 3 illustrate the lack of significant differences in the amount of scale insects found on the plants tested.

In contrast to the coffee mulch, the neem and orange oil treatments did significantly affect cycad mortality (Table 1 ), but in most cases final insect counts could not be taken because of the lack of leaves on the plants tested. At the end of the experiment, neem oil and orange oil treatments caused $80 \%$ mortality, which would likely have led to $100 \%$ mortality because of the total defoliation of the last surviving plant that likely would have died if the experiment had been conducted longer.

The differences in insects per square centimeter between the control and coffee treatment were not significant in the debao cycads or in

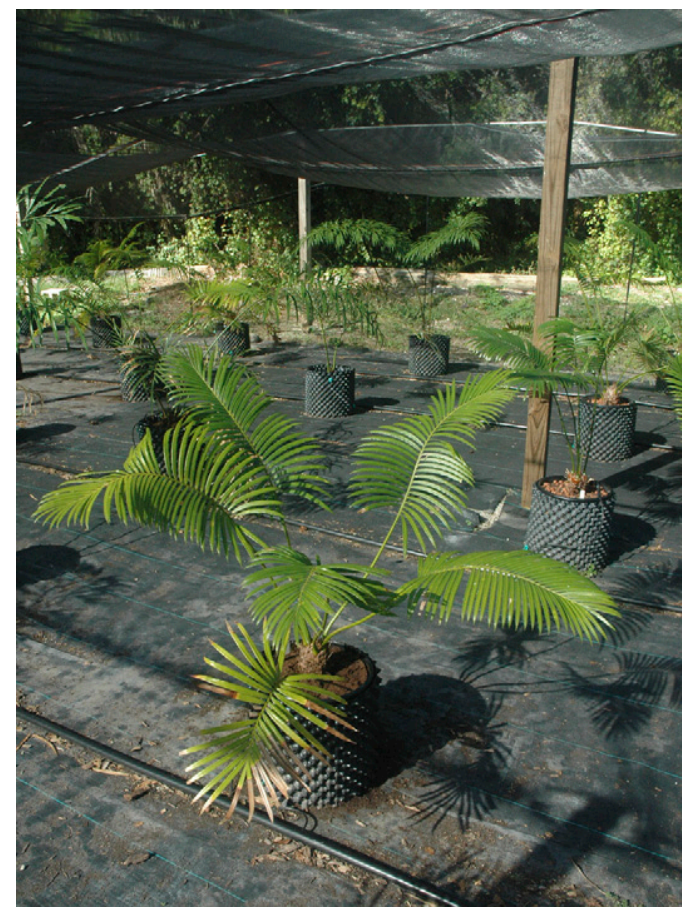

Fig. 2. Shade experiment testing coffee mulch treatment, a natural product reported to have insecticidal properties, for control of cycad aulacaspis scale on debao cycads and fadang. Photograph of debao and fadang cycads in $63 \%$ shade at Montgomery Botanical Center, Coral Gables, FL, in 2011. Mulch treatment consisted of $500 \mathrm{~mL}$ spent coffee per week; $1 \mathrm{~mL}=0.0338 \mathrm{fl} \mathrm{oz}$.

the fadang (Figs. 3 and 4). Soil pH differences were confirmed between control and coffee treatments, lowering $\mathrm{pH}$ by an average $( \pm \mathrm{SE})$ of $0.48 \pm 0.19$ [linear contrast, $P=0.017, \mathrm{~F}$ ratio $=$ $6.47, \mathrm{df}$ (numerator, denominator) $=$ $1,26]$ with the coffee mulch. There was no significant change in EC through the course of the experiment.

\section{Discussion}

Orange oil was extremely toxic to the debao cycad, killing four out of five plants during the first experiment. The surviving debao cycads had no leaves and were nearly dead at the end of the experiment. This result disagrees with a prior study (Hollingsworth, 2005), stating that limonene solutions generally cause no harm to plants with waxy leaves, such as cycads. However, Hollingsworth (2005) did show that limonene, the main ingredient in orange oil, has a phytotoxic effect on various plants without waxy leaves. The debao cycad has thin leaflets without a prominent waxy cuticle, and perhaps that plays a role in the phytotoxic effect of the orange oil. Orange oil was not tested on fadang.

Neem oil also had a negative effect on debao cycads, leaving only one of the five plants in good condition at the end of the experiment. One plant died early on and three more plants were observed dead at the end of the experiment. Neem oil also appeared to raise $\mathrm{pH}$, but not significantly (linear contrast, $P=0.507$, $\mathrm{F}$ ratio $=4.20, \mathrm{df}=1,26)$. Neem oil was not tested on fadang.

During the experiment, many insects and other arthropods were

Table 1. Mortality of debao cycads being treated for control of cycad aulacaspis scale. Treatments based on natural products with potential insecticidal properties were compared. Plants were treated from May to Nov. 2010 at Montgomery Botanical Center, Coral Gables, FL.

\begin{tabular}{|c|c|c|c|c|c|}
\hline \multirow[b]{2}{*}{ Treatment $^{\mathrm{z}}$} & \multirow{2}{*}{$\begin{array}{c}\text { Dead } \\
\text { plants (no.) }\end{array}$} & \multirow{2}{*}{$\begin{array}{c}\text { Total } \\
\text { plants (no.) }\end{array}$} & \multirow{2}{*}{$\begin{array}{c}\text { Plant mortality proportion } \\
\text { (no. dead/total) }\end{array}$} & \multicolumn{2}{|c|}{ Plant mortality } \\
\hline & & & & Lower 95\% CL CL $^{y}$ & Upper 95\% CL \\
\hline Control $(n=5)$ & 0 & 5 & 0 & 0 & 0.522 \\
\hline Orange oil $(n=5)$ & 4 & 5 & 1 & 0.376 & 0.964 \\
\hline Tea $(n=5)$ & 1 & 5 & 0.2 & 0.036 & 0.624 \\
\hline 0.5 Tea $(n=5)$ & 1 & 5 & 0.2 & 0.036 & 0.624 \\
\hline Mulch + tea $(n=5)$ & 1 & 5 & 0.2 & 0.036 & 0.624 \\
\hline
\end{tabular}

${ }^{\mathrm{z}} \mathrm{Neem}$ oil $=60 \mathrm{~mL} / \mathrm{gal}$ neem oil applied in one 0.5 -gal treatment per week; orange oil $=60 \mathrm{~mL} / \mathrm{gal}$ orange oil applied in one 0.5 -gal treatment per week; tea $=500 \mathrm{~mL} / \mathrm{gal}$ spent coffee tea applied in one 0.5 -gal treatment per week; 0.5 tea $=$ coffee tea treatment above diluted in a $1: 1$ ratio with water applied in one 0.5 -gal treatment per week; 0.5 mulch $=250 \mathrm{~mL}$ spent coffee per week; mulch $=500 \mathrm{~mL}$ spent coffee per week; mulch + tea $=500 \mathrm{~mL}$ spent coffee per week $+500 \mathrm{~mL} / \mathrm{gal}$ spent coffee tea applied in one 0.5 -gal treatment per week; $1 \mathrm{~mL} / \mathrm{gal}=0.0338 \mathrm{fl} \mathrm{oz} / \mathrm{gal}=0.2642 \mathrm{~mL} \cdot \mathrm{L}^{-1}, \mathrm{l} \mathrm{gal}=3.7854 \mathrm{~L}$.

${ }^{\mathrm{y}}$ Confidence limits based on binomial distribution. 
A

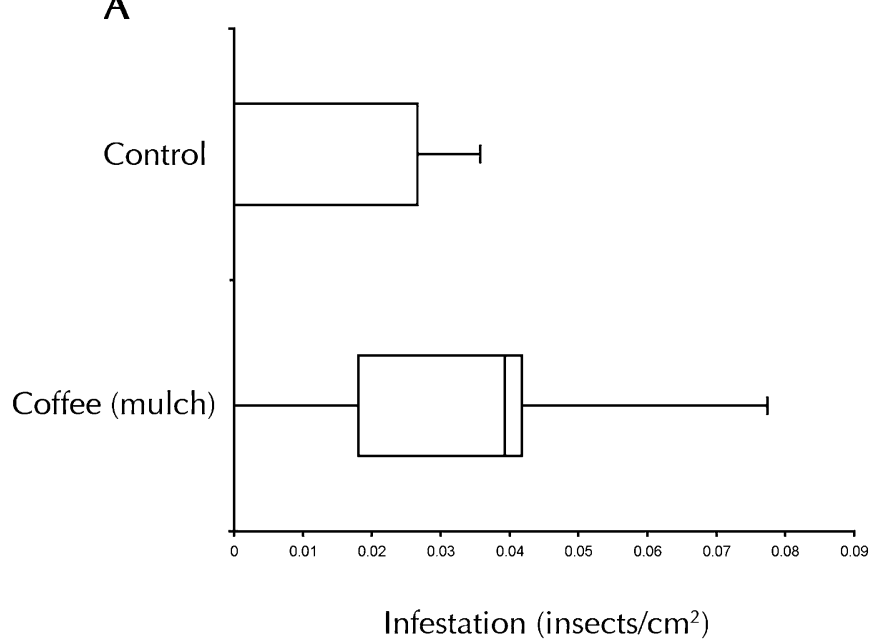

C

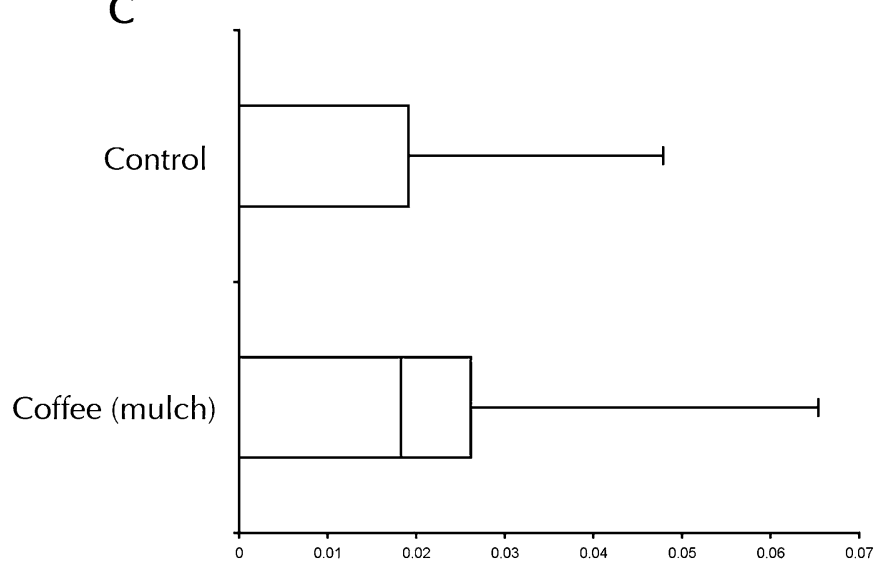

Infestation (insects $/ \mathrm{cm}^{2}$ )
B

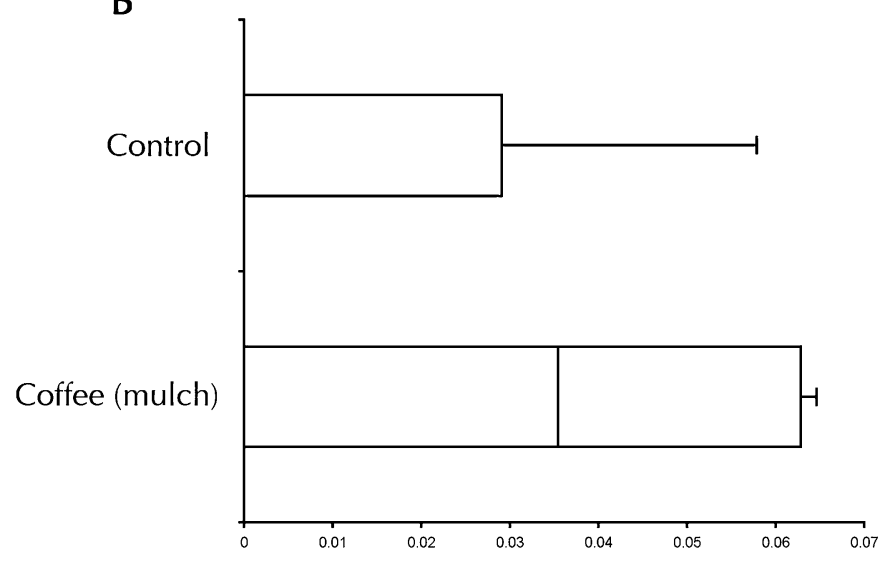

Infestation (insects $/ \mathrm{cm}^{2}$ )

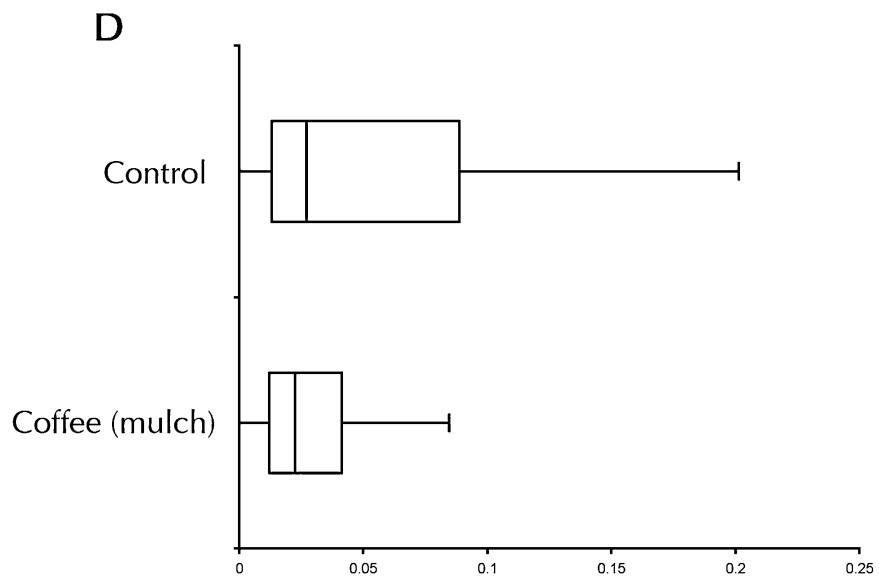

Infestation (insects $/ \mathrm{cm}^{2}$ )

Fig. 3. Boxplots showing how use of spent coffee grounds, a natural product reported to have insecticidal properties, affects infestation by cycad aulacaspis scale on debao cycads. Boxplots show minimum (min), median of the lower half (Q1), median (med), median of the upper half $(\mathrm{Q} 3)$, and maximum $(\max )$ insects per square centimeter recorded from control and coffee mulched debao cycads. Each plant had five leaflets sampled randomly and the total number of insects on the five leaflets was recorded for each plant on four unique dates. (A) Five controls vs. five mulch treatments were tested in full sun. On 23 Sept. 2010 , the mean of the controls was 0.013 insects $/ \mathrm{cm}^{2}$ and the mean of the coffee treatments was 0.064 insects $/ \mathrm{cm}^{2}, \mathrm{but}$ the difference was not significant $\left[P=0.240, v^{2}=0.168, \mathrm{~F}\right.$ ratio $=1.61$, df (numerator, denominator) $\left.=1,8\right]$. Insects per square centimeter of control $(\min =0, Q 1=0, \operatorname{med}=0, Q 3=0.027, \max =0.036)$ and $\operatorname{coffee}(\min =0, Q 1=0.018, \mathrm{med}=0.039, \mathrm{Q} 3=$ $0.042, \max =0.218$ ). (B) Five controls vs. five mulch treatments were tested in full sun. On 8 Nov. 2010, the mean of the controls was 0.017 insects $/ \mathrm{cm}^{2}$ and the mean of the coffee treatments was 0.033 insects $/ \mathrm{cm}^{2}$, but the difference was not significant $\left(P=0.432, v^{2}=0.079, \mathrm{~F}\right.$ ratio $\left.=0.68, \mathrm{df}=1,8\right)$. Insects per square centimeter of control $(\mathrm{min}=0, \mathrm{Q} 1=0, \mathrm{med}=0$, $\mathrm{Q} 3=0.029, \max =0.058)$ and coffee $(\min =0, Q 1=0, \operatorname{med}=0.036, Q 3=0.063, \max =0.065) .(C)$ Ten controls vs. 10 mulch treatments were tested in shade. On 1 Sept. 2011, the mean of the control was 0.019 insects $/ \mathrm{cm}^{2}$ and the mean of the coffee treatment was 0.030 insects $/ \mathrm{cm}^{2}$, but the difference was not significant $\left(P=0.640, r^{2}=0.012, \mathrm{~F} \mathrm{ratio}=0.23, \mathrm{df}=1,18\right)$. Insects per square centimeter of control $(\min =0, Q 1=0, \operatorname{med}=0, Q 3=0.019, \max =0.134)$ and coffee $(\mathrm{min}=0, \mathrm{Q} 1=0, \mathrm{med}=0.018$, Q3 = 0.026, $\max =0.177)$. (D) Ten controls vs. 10 mulch treatments were tested in shade. On 3 Nov. 2011 , the mean of the control was 0.291 insects $/ \mathrm{cm}^{2}$ and the mean of the coffee treatment was 0.246 insects $/ \mathrm{cm}^{2}$, but the difference was not significant $\left(P=0.894, v^{2}=0.001, \mathrm{~F}\right.$ ratio $\left.=0.02, \mathrm{df}=1,18\right)$. Insects per square centimeter of $\operatorname{control}(\mathrm{min}=0, \mathrm{Q} 1=0.013, \mathrm{med}=$ $0.027, \mathrm{Q} 3=0.089, \max =0.234)$ and coffee $(\min =0, \mathrm{Q} 1=0.012, \operatorname{med}=0.023, \mathrm{Q} 3=0.041, \mathrm{max}=0.029) ; 1 \mathrm{insect} / \mathrm{cm}^{2}=$ 6.4516 insects $/$ inch $^{2}$.

observed living in the coffee grounds mulch [centipedes (Chilopoda), wasps (Hymenoptera), and cockroaches (Dictyoptera)], despite frequent reapplication of spent grounds. Although counts were not taken on these insects, this suggests no direct toxicity of spent coffee grounds on living insects, thereby calling into question the use of grounds as an insecticide.

The spent coffee grounds mulch tended to decay over time. The roots of the coffee mulched plants were observed to be in poor condition on the completion of the experiment, in contrast to the control plants. This agrees with past findings that fungal and bacterial problems in potted plants 
A

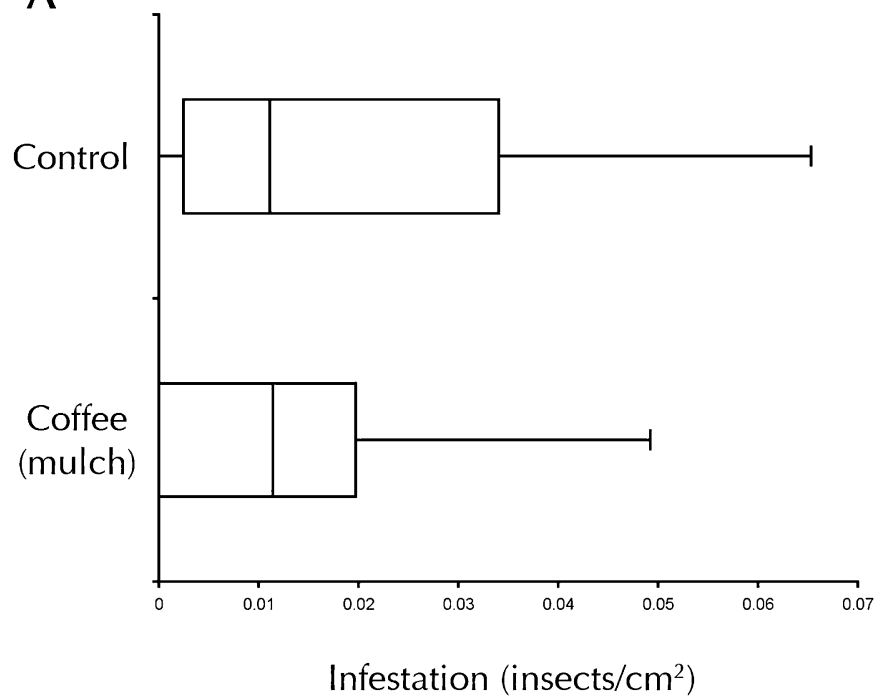

B

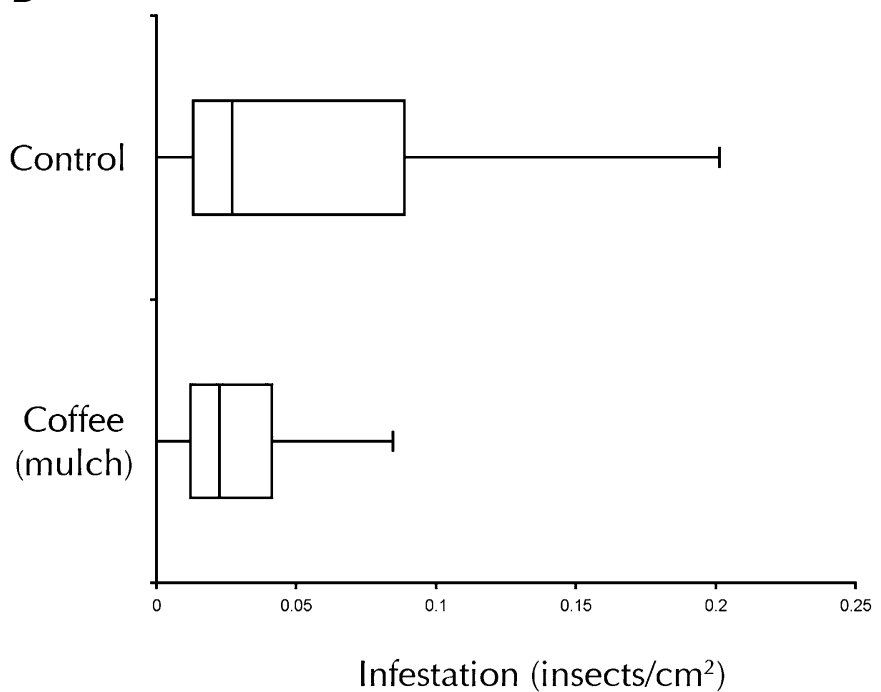

Fig. 4. Boxplots showing how use of spent coffee grounds, a natural product reported to have insecticidal properties, affects infestation by cycad aulacaspis scale on fadang. Boxplot showing minimum (min), median of the lower half $(Q 1)$, median (med), median of the upper half $(\mathrm{Q} 3)$, and maximum ( $\max )$ comparing insects per square centimeter recorded from control and coffee mulched fadang. (A) Ten controls vs. 10 mulch treatments were tested in shade. On 1 Sept. 2011, the mean of the control was 0.020 insects $/ \mathrm{cm}^{2}$ and the mean of the coffee treatment was 0.084 insects $/ \mathrm{cm}^{2}$, but the difference was not significant $[P=$

$0.379, \mathrm{r}^{2}=\mathbf{0 . 0 4 3}, \mathrm{F}$ ratio $=0.81, \mathrm{df}$ (numerator, denominator $\left.)=1,18\right]$. Insects per square centimeter of control $(\mathrm{min}=0, \mathrm{Q} 1=$ $0.003, \mathrm{med}=0.011, \mathrm{Q} 3=0.034, \max =0.065)$ and $\operatorname{coffee}(\min =0, \mathrm{Q} 1=0, \operatorname{med}=0.011, \mathrm{Q} 3=0.020, \mathrm{max}=0.710)$. $(\mathrm{B}) \mathrm{Ten}$ controls vs. 10 mulch treatments were tested in shade. On 3 Nov. 2011 , the mean of the control was 0.065 insects $/ \mathrm{cm}^{2}$ and the mean of the coffee treatment was 0.057 insects $/ \mathrm{cm}^{2}$, but the difference was not significant $\left(P=0.847, v^{2}=0.002, \mathrm{~F}\right.$ ratio $=0.04$, $\mathrm{df}=1,18)$. Insects per square centimeter of control $(\mathrm{min}=0, \mathrm{Q} 1=0.013, \mathrm{med}=0.027, \mathrm{Q} 3=0.089, \mathrm{max}=0.234)$ and coffee $(\min =0, \mathrm{Q} 1=0.012, \mathrm{med}=0.023, \mathrm{Q} 3=0.041, \mathrm{max}=0.327) ; 1 \mathrm{insect} / \mathrm{cm}^{2}=6.4516 \mathrm{insects} / \mathrm{inch}^{2}$.

mulched with coffee grounds had an increased incidence of disease (Smith, 2000). Despite these qualitative observations, the presence of fungus in coffee mulch did not affect plant mortality (Table 1 ).

Plants treated with coffee mulch were shown to have a significantly lower soil $\mathrm{pH}$ than control plants, but no difference in EC was found. Contrary to early studies on the use of coffee grounds as an insecticide or a pest deterrent, we did not find an effect on insect number when plants were treated with coffee.

Comparisons of infestation among the control, neem oil, and orange oil were unable to be made because of the high incidence of plant mortality following the application of the neem and orange oil treatments.

Scale insects have an armored shell and most insecticides cannot penetrate their cover. This could be the reason the coffee tea (topical treatment) did not work. The coffee mulch treatment would only have been effective in treating the scale if it were it absorbed as a systemic. It is not known if there are chemicals in coffee grounds that are systemics, but no benefit to using coffee mulch was shown in our experiment.

Thus, despite recent enthusiasm for this recycled resource, spent coffee grounds do not appear to protect cycads from CAS.

\section{Literature cited}

Ashok, R., J. Bland, M. Doolittle, A. Lax, R. Boopathy, and M. Folkins. 2007. Effect of orange oil extract on the formosan subterranean termite (Isoptera: Rhinotermitidae). J. Econ. Entomol. 100(3): 880-885.

Bilderback, T.E. 2001. Using the PourThru procedure for checking $\mathrm{EC}$ and $\mathrm{pH}$ for nursery crops. North Carolina State Univ. Hort. Info. Lflt. No. 450. 25 Jan. 2013. <http://www.ces.ncsu.edu/depts/hort/ hil/pdf/hil-450.pdf>.

Broome, T. 2007. Coffee, cycads' new best friend? Cycad Nwsl. 30(4):44-46.

Cave, R.D. 2006. Biological control agents of the cycad aulacaspis scale, Aulacaspis yasumatsui. Proc. Florida State Hort. Soc. 119:422-424.

Cavins, T.J., B.E. Whipker, W.C. Fonteno, B. Harden, I. McCall, and J.L. Gibson. 2000. Monitoring and managing $\mathrm{pH}$ and
EC using the PourThru extraction method. North Carolina State Univ. Hort. Info. Lflt. No. 590.

Emshousen, C., C. Mannion, and H. Glenn. 2004. Management of cycad Aulacaspis yasumatsui Takagi. Proc. Florida State Hort. Soc. 117:305-307.

Fiaz, M., A. Hameed, M. ul Hasan, and W. Wakil. 2012. Efficacy of plant extracts on some cotton (Gossypium hirsutum) pests: Amarasca bigutulla bigutulla Ishida and Thrips tabaci Lindeman. Pak. J. Zool. 44(1):277-283.

Germain, J.F. and G.S. Hodges. 2007. First report of Aulacaspis yasumatsui (Hemiptera: Diaspididae) in Africa (Ivory Coast), and update on distribution. Fla. Entomol. 90(4):755-756.

Guirado, M.M. and H.E.M.M.C. Bicudo. 2007. Effect of used coffee grounds on larval mortality of Aedes aegypti L. (Diptera: Culicidae): Suspension concentration and age versus efficacy. BioAssay 2(5):1-7.

Hodges, G.S., F.W. Howard, and E.A. Buss. 2003. Update on management methods for cycad aulacaspis scale. Entomol. Nematol. Dept., Florida Coop. Ext. Serv., Inst. Food Agr. Sci., Univ. Florida, ENY-680. 25 Jan. 2013. <http://www. freshfromflorida.com/pi/pest-alerts / aulacaspis-yasumatsui.html>. 
Hollingsworth, R.G. 2005. Limonene, a citrus extract, for control of mealybugs and scale insects. J. Econ. Entomol. 98(3):772-779.

Howard, F.W., A. Hamon, M. McLaughlin, T. Weissling, and S. Yang. 1999. Aulacaspis yasumatsui (Hemiptera L Sternorrhyncha: Diaspididae), a scale insect pest of cycads recently introduced into Florida. Fla. Entomol. 82(1):13-27.

Howard, F.W. and T.J. Weissling. 1999. Questions and answers about the cycad aulacaspis scale insect. Proc. Florida State Hort. Soc. 112:243-245.

International Union for Conservation of Nature. 2010. IUCN red list of threatened species. Version 2010.1. 14 Apr. 2010. <http://www.iucnredlist.org>.

Kelly, K. 2008. Saving the sago with coffee grounds: Coffee grounds may give a boost to sick cycads. Orlando Sentinel, p. D5. 25 Jan. 2013. <http://www.cycadsg. org/publications/CAS/coffee-groundsMar-08.htm>.

Laranja, A.T., A.J. Manzato, and H.E.M.C. Bicudo. 2003. Effects of caffeine and used coffee grounds on biological features of Aedes aegypti (Diptera, Culicidae) and their possible use in alternative control. Genet. Mol. Biol. 26(4): 419-429.

Mamoon-ur-Rashid, M., M.K. Khattak, and K. Abdullah. 2012. Residual toxicity and biological effects of neem (Azadirachta indica) oil against cotton mealybug, Phenacoccus solenopsis Tinsley (Sternorrhyncha: Pseudococcidae). Pak. J. Zool. 44(3):837-843.
Mannion, C. 2003. High risk insect pests: Monitoring and diagnosis. Proc. Florida State Hort. Soc. 116:78-79.

Marler, T.E. and R. Muniappan. 2006. Pests of Cycas micronesica leaf, stem, and male reproductive tissues with notes on current threat status. Micronesica 39(1):1-9.

Miyashira, C.H., D.G. Tanigushi, A.M Gugliotta, and D.Y.A.C. Santosa. 2011. Influence of caffeine on the survival of leaf-cutting ants Atta sexdens rubropilosa and in vitro growth of their mutualistic fungus. Pest Mgt. Sci. 68:935-940.

Popenoe, J. 2010. Sago, king sago palm Cycas revoluta. 31 Jan. 2013. <http:// lake.ifas.ufl.edu/agriculture/nurseryproduction/documents/Sago.pdf $>$.

Rasband, W.S. 2012. ImageJ. 31 Jan. 2013. <http://imagej.nih.gov/ij/>.

Smith, C.W. 2000. Coffee grounds in flower pots. 18 July 2012 . <http://aces.nmsu. edu/ces/yard/2000/111800.html\#2>.

Smith, T.R. and R.D. Cave. 2006. Pesticide susceptibility of Cybocephalus nipponicus and Rhyzobius lophanthae (Coleoptera: Cybocephalidae, Coccinellidae). Fla. Entomol. 89(4):502-507.

Tang, Y.Q., A.A. Weathersbee, III, and R.T. Mayer. 2002. Effect of neem seed extract on the brown citrus aphid (Homoptera: Aphididae) and its parasitoid Lysiphlebus testaceipes (Hymenoptera: Aphidiidae). Environ. Entomol. 31(1): 172-176.

Weissling, T.J., F.W. Howard, and A.B. Hamon. 1999. Cycad aulacaspis scale,
Aulacaspisyasumatsui Takagi (Insecta: Homoptera: Sternorrhyncha: Diaspididae). Entomol. Nematol. Dept., Florida Coop. Ext. Serv., Inst. Food Agr. Sci., Univ. Florida, EENY-096. 18 July 2012. <http://polkhort.ifas.ufl.edu/documents/ publications/Cycad\%20Scale.pdf>.

Whipker, B.E., T.J. Cavins, and W.C. Fonteno. 2001. 1, 2, 3's of PourThru. 6 July 2012. <http://www.ces.ncsu.edu/ floriculture/crop/crop_PTS.htm>.

Whitelock, L.M. 2002. The cycads. Timber Press, Portland, OR.

Wiese, C., D. Amalin, R. Coe, and C. Mannion. 2005. Effects of the parasitic wasp, Coccobius Fulvus, on cycad aulacaspis scale, Aulacaspis yasumatsui, at Montgomery Botanical Center, Miami, Florida. Proc. Florida State Hort. Soc. 118:319-321.

Wiese, C. and C. Mannion. 2007. Managing cycad aulacaspis scale (Aulacaspis yasumatsui Takagi) at Montgomery Botanical Center, p. 64-72. In: A. Vovides, D.W. Stevenson, and R. Osborne (eds.). Proc. Cycad 2005: 7th Intl. Conf. Cycad Biol. New York Botanical Garden Press, Bronx, NY.

Woods, C. 2007. UF researchers test natural predators to control sago palm threat. 31 Jan. 2013. <http://news.ufl. edu $/ 2007 / 05 / 10 /$ sago-palm $/>$.

Zunino, M.P., V.A. Areco, and J.A. Zygadlo. 2012. Insecticidal activity of three essential oils against two new important soybean pests: Sternechus pinguis (Fabricius) and Rhyssomatus subtilis Fiedler (Coleoptera: Curculionidae). Boletín Latinoamericano y del Caribe de Plantas Medicinales y Aromáticas 11(3):269-277. 